\title{
METHOD TO ESTIMATE SOIL MACROPOROSITY AND MICROPOROSITY BASED ON SAND CONTENT AND BULK DENSITY(1)
}

\author{
Rubismar Stolf ${ }^{(2)}$, Álvaro de Mendonça Thurler ${ }^{(3)}$, Osny Oliveira \\ Santos Bacchi ${ }^{(4)} \&$ Klaus Reichardt ${ }^{(5)}$
}

\begin{abstract}
SUMMARY
Macroporosity is often used in the determination of soil compaction. Reduced macroporosity can lead to poor drainage, low root aeration and soil degradation. The aim of this study was to develop and test different models to estimate macro and microporosity efficiently, using multiple regression. Ten soils were selected within a large range of textures: sand (Sa) $0.07-0.84$; silt $0.03-0.24$; clay $0.13-$ $0.78 \mathrm{~kg} \mathrm{~kg}^{-1}$ and subjected to three compaction levels (three bulk densities, BD). Two models with similar accuracy were selected, with a mean error of about $0.02 \mathrm{~m}^{3} \mathrm{~m}^{-3}(2 \%)$. The model $\mathrm{y}=\mathrm{a}+\mathrm{b} . \mathrm{BD}+\mathrm{c}$. Sa, named model 2 , was selected for its simplicity to estimate Macro (Ma), Micro (Mi) or total porosity (TP): $\mathrm{Ma}=\mathbf{0 . 6 9 3}$ $-0.465 \mathrm{BD}+0.212 \mathrm{Sa} ; \mathrm{Mi}=0.337+0.120 \mathrm{BD}-0.294 \mathrm{Sa} ; \mathrm{TP}=1.030-0.345 \mathrm{BD}-0.082$ $\mathrm{Sa}$; porosity values were expressed in $\mathrm{m}^{3} \mathrm{~m}^{-3}$; BD in $\mathrm{kg} \mathrm{dm}^{-3}$; and Sa in $\mathrm{kg} \mathrm{kg}^{-1}$. The model was tested with $\mathbf{7 6}$ datum set of several other authors. An error of about $0.04 \mathrm{~m}^{3} \mathrm{~m}^{-3}(4 \%)$ was observed. Simulations of variations in BD as a function of Sa are presented for $\mathrm{Ma}=0$ and $\mathrm{Ma}=\mathbf{0 . 1 0}(\mathbf{1 0} \%)$. The macroporosity equation was remodeled to obtain other compaction indexes: a) to simulate maximum bulk density (MBD) as a function of Sa (Equation 11), in agreement with literature data; b) to simulate relative bulk density (RBD) as a function of $\mathrm{BD}$ and $\mathrm{Sa}$ (Equation 13); c) another model to simulate RBD as a function of Ma and Sa (Equation 16), confirming the independence of this variable in relation to Sa for a
\end{abstract}

(1) Part has been presented in the Brazilian Congress of Soil Science, 29, 2003, Ribeirão Preto. Received for publication in October 2009 approved in december 2010

(2) Associate Professor of Department of Natural Resources and Environmental Protection, Federal University of São Carlos, UFSCar, CEP 13600-970, Araras, SP. Brazil. Home page: http://www.cca.ufscar.br/drnpa/hprubismar.htm. E-mail: rubismar@cca.ufscar.br

(3) Agronomist, Dr., Federal Rural University of Rio de Janeiro, Campus Dr. Leonel Miranda / UFRRJ, Estrada do Açúcar, 5 km, Penha, 28020-560, Campos, RJ, Brazil. E-mail: clmufrrj.rol @ terra.com.br

(4) Assistant Professor of the Laboratory of Soil Physics , University of São Paulo, USP, POB 96, 13418-900 Piracicaba, SP, Brazil. E-mail: osny@cena.usp.br

(5) Full Professor of the Laboratory of Soil Physics , University of São Paulo, USP, POB 96, 13418-900 Piracicaba, SP, Brazil. Email: klaus@cena.usp.br 
fixed value of macroporosity and, also, proving the hypothesis of Hakansson \& Lipiec that $\mathrm{RBD}=0.87$ corresponds approximately to $10 \%$ macroporosity $(\mathrm{Ma}=$ $0.10 \mathrm{~m}^{3} \mathrm{~m}^{-3}$ ).

Index terms: degree of compaction, modeling, macropore, texture, maximum bulk density, relative bulk density.

\title{
RESUMO: MÉTODO DE ESTIMATIVA DA MACROPOROSIDADE E DA MICROPOROSIDADE POR MEIO DO TEOR DE AREIA E DA DENSIDADE DO SOLO
}

\begin{abstract}
A macroporosidade é um atributo do solo utilizado para estudos do seu grau de compactação. Valores baixos de macroporosidade podem resultar em má drenagem, baixa aeração e aumento da resistência do solo à penetração de raízes, sendo um dos indicadores de degradação do solo. Os objetivos deste trabalho foram desenvolver e testar modelos para estimativa da macro e da microporosidade, utilizando regressão múltipla, como uma proposta para levantamentos expeditos. Dez amostras de solos com diferentes composições granulométricas - areia: 0,07-0,84; silte: 0,03-0,24; e argila: 0,13-0,78 kg kg-1 - foram submetidas a três níveis de densidade do solo (DS). Dois modelos foram selecionados, apresentando acurácias semelhantes, com erro médio em torno de $0,02 \mathrm{~m}^{3} \mathrm{~m}^{-3}(2 \%)$. O modelo $y=a+b . D s+c$ areia, denominado modelo 2 , aplicado tanto para macro e micro como para porosidade total, $\mathrm{Pt}$, foi selecionado pela sua simplicidade: macro $=0,693-0,465 \mathrm{Ds}+0,212$ areia; micro $=0,337+0,120 \mathrm{Ds}-0,294$ areia; $P t=1,030-0,345 \mathrm{Ds}-0,082$ areia. As porosidades foram expressas em $\mathrm{m}^{3} \mathrm{~m}^{-3}$, e a areia, em $\mathrm{kg} \mathrm{kg}^{-1}$. Os modelos foram testados em 76 dados, medidos por diferentes autores, obtendo-se um erro médio da ordem de $0,04 \mathrm{~m}^{3} \mathrm{~m}^{-3}$ (4\%). Foram apresentadas simulações da variação de Ds com areia na faixa de compactação para macro de 0 a $0,10 \mathrm{~m}^{3} \mathrm{~m}^{-3}$. A equação da macroporosidade foi remodelada para obter outros indicadores de compactação: a) para simular densidade máxima do solo em função da areia (Equação 11), apresentando boa concordância com dados da literatura; $b$ ) um modelo de densidade relativa do solo em função da Ds e areia (Equação 13); e c) um outro modelo para simular a densidade relativa do solo em função da macro e areia (Equação 16), confirmando a independência dessa variável em relação à areia para um valor fixo da macroporosidade e, também, comprovando a hipótese de Hakansson \& Lipiec, de que o valor 0,87 representa aproximadamente a macroporosidade $10 \%\left(0,10 \mathrm{~m}^{3} \mathrm{~m}^{-3}\right)$.
\end{abstract}

Termos de indexação: grau de compactação, modelagem, macroporosidade, textura, densidade do solo, densidade máxima, densidade relativa.

\section{INTRODUCTION}

Soil macro and microporosity have been used in important studies on soil aeration, soil water dynamics and soil compaction (Scardua, 1972; Freire, 1975; Primavesi et al.,1984) with a notable intensification in this decade in studies on soil management (Andreola et al., 2000; Beutler et al., 2001; Stone \& Silveira, 2001; Oliveira et al., 2001; Lima \& Andrade, 2001; Albuquerque \& Reinert, 2001; Souza et al., 2001; Marques et al., 2002; Pedrotti et al., 2003; Ghini et al., 2003; Pott \& De Maria, 2003). Macroporosity, particularly, is considered an excellent indicator of soil degradation, due to its relation with compaction. According to Hakansson \& Lipiec (2000), several reports indicate a value of $10 \%\left(0.10 \mathrm{~m}^{3} \mathrm{~m}^{-3}\right)$ macroporosity as a critical limit for soil aeration, similarly to Erickson (1982), Drewry \& Paton (2001),
Centurion et al. (2007) and Melo Filho et al. (2007). However, several extension reports and agricultural enterprise users take soil bulk density as an indicator of soil compaction, an approach that limits the interpretation of soil compaction in the field because the macroporosity of an apparently compacted soil with high bulk density can be non-limiting, associated to a sand content and vice-versa; therefore, macroporosity would allow a better indication of the compaction state of a soil than bulk density (Stolf, 1987).

Simple and expeditious methods have been proposed for the evaluation of soil physical properties involving a large number of samples. A typical example of research with this aim is the study of Amado et al. (2007), who evaluated the adoption of the "Soil quality kit test" of the USDA-ARS in Brazil, and found that the estimation errors were larger than those of standard analytical procedures. The soil 
quality kits however, are accessible to the farmer at lower cost, demand less equipment, besides being faster, allowing sampling at a greater number of points. Considering that the "Soil quality kit test" does not cover macro and microporosity, a practical method for these properties is in demand. The difficulty of including macro and microporosity in tests with the "Soil quality kit" can be understood by the procedure description, which recommends that after collecting an undisturbed soil sample for bulk density determination, all soil material within the cylinder should be transferred to a plastic bag for the reuse of the cylinder (Amado et al., 2007). This procedure makes it impossible to determine the macro and microporosities in the laboratory. For this kind of measurement a large number of cylinders would be needed, as well as a careful sample transport to the laboratory. In addition, the laboratory would have to be prepared to deal with a large number of samples in a short time to provide prompt information on soil management in the field. Therefore, an alternative, simplified method for the determination of the macro and microporosity would be very handy in this context.

Soil properties such as texture can be mathematically correlated to plant attributes (Santos et al., 2008). When correlated for the estimation of another soil property, the equation is called pedotransfer function, with the advantages of greater facility and lower costs (Fidalski \& Tormena, 2008). They are in general obtained by multiple regression. There are applications correlating soil bulk density, $\mathrm{C}$ and water contents for the estimation of soil water retention curves (Fidalski \& Tormena, 2008); as well as a model to describe the relation between relative saturation, macroporosity and water content presented by Carter \& Johnston (1989). Several reports focused on the estimation of drainable porosity based on soil properties: sand, bulk density, total porosity, organic matter, and water-dispersed clay (Mello et. al., 2007) or on hydraulic conductivity due to water table lowering (Feitoza, 2006; Ribeiro et al., 2007). Within the context of the study subject, soil compaction, Corsini \& Ferraudo (1999) developed two expressions to estimate soil bulk density from macroporosity for a Dark Red Latosol. Results indicated a linear behavior of variables with very high $\mathrm{R}^{2}$ values 0.97 and 0.91 . It represents a specific model (Macro x BD) developed for a specific location, soil type and texture. The question raised in this paper is the possibility of generalizing the model to estimate macroporosity for different soils by including a texture component as additional variable. For this purpose, data is not only required for a wide textural range, but also for several bulk densities within each texture. The objective of this study was to test different models for the estimation of macro and microporosity using texture components and soil bulk density as independent variables, as a proposal for expeditious surveys.

\section{MATERIAL AND METHODS}

Models were obtained using data of 10 soils that represent a wide textural range were sampled in different sugarcane fields in the State of São Paulo, Brazil, (Table 1).

Samples were air-dried and sieved through $2 \mathrm{~mm}$ mesh according to Wu et al. (1990), who used this procedure for seven soil samples with different particle size distribution to study pores, particles and aggregate sizes as related to soil water retention curves. Other authors also used the sieving procedure to determine soil compaction levels in pot experiments and observe the influence on crop productivity (Beutler et al., 2005).

Thereafter, cylinders with a volume of $54.29 \mathrm{~cm}^{3}$ (diameter $4.80 \mathrm{~cm}$, height $3.00 \mathrm{~cm}$ ) and a nylon screen attached at the bottom were filled with sieved soil. Three compaction levels were established in these cylinders: 1) loose soil; 2) soil compressed with a wooden piston, reducing soil height in the cylinder by about

Table 1. Soil characterization: great group, sampling depth, texture class, sand (Sa), clay (Cl), and carbon content ( $C$ contents)

\begin{tabular}{|c|c|c|c|c|c|c|}
\hline Soil & Great group & Depth & Texture class & $\mathrm{Sa}$ & $\mathrm{Cl}$ & $\mathbf{C}$ \\
\hline & & $\mathrm{cm}$ & & $\mathrm{kg} \mathrm{kg}^{-1}$ & & $\%$ \\
\hline 1 & Red - Yellow Latosol (Oxisol) & $5-20$ & loamy sand & 0.84 & 0.13 & 0.72 \\
\hline 2 & Red - Yellow Argisol (Ultisol) & $5-15$ & sandy clay loam & 0.71 & 0.22 & 0.77 \\
\hline 3 & Red - Latosol (Oxisol) & $40-80$ & sandy clay loam & 0.67 & 0.30 & 0.72 \\
\hline 4 & Red - Yellow Argisol (Ultisol) & $5-15$ & sandy clay loam & 0.64 & 0.21 & 1.28 \\
\hline 5 & Red Latosol (Oxisol) & $15-20$ & sandy clay & 0.52 & 0.40 & 1.28 \\
\hline 6 & Red nitosol & $5-20$ & clay loam/clay & 0.37 & 0.40 & 0.93 \\
\hline 7 & Red nitosol & $10-25$ & Clay & 0.30 & 0.59 & 1.35 \\
\hline 8 & Red nitosol & $0-15$ & Clay & 0.17 & 0.59 & 1.48 \\
\hline 9 & Red Latosol (Oxisol) & $0-20$ & Clay & 0.07 & 0.71 & 1.75 \\
\hline 10 & Red Latosol (Oxisol) & $5-25$ & Clay & 0.07 & 0.78 & 1.54 \\
\hline
\end{tabular}


$0.5 \mathrm{~cm} ; 3)$ soil height reduced by about $1 \mathrm{~cm}$. At each compaction level the following measurements were taken: soil bulk density (BD), total porosity (TP), macro $(\mathrm{Ma})$ and microporosity $(\mathrm{Mi})$ at a water potential of $-60 \mathrm{hPa}$, corresponding to a $0.05 \mathrm{~mm}$ pore diameter in the soil water retention curve and taken as the limit between macro and microporosity (Kiehl, 1979). Sand, silt and clay contents were established by the pipette method (Baver, 1966), using a $5 \% \mathrm{NaOH}$ solution as a dispersing agent, under slow shaking for $16 \mathrm{~h}$. The sand fraction was obtained by wet sieving (sieve 270, diameter $0.052 \mathrm{~mm}$ ), particle soil density (PD) by the pycnometer method (Blake, 1965) and BD by gravimetric analysis using the sample dry weight and the corresponding volume after each compaction level. The TP was calculated based on BD and PD. Macro was calculated by the difference between TP and Mi. In this way 30 results were obtained (10 textures $\mathrm{x} 3$ compaction levels).

Mathematical models were obtained using the multiple regression technique (Spiegel, 1971; Stolf, 1996), as follows. Firstly, five variables were used for model adjustment: sand (Sa), silt (Si) and clay $(\mathrm{Cl})$ contents, and $\mathrm{BD}$ and $\mathrm{PD}$, used as the ratio $\mathrm{BD} / \mathrm{PD}$ (based on the relation TP $=[1-\mathrm{BD} / \mathrm{PD}])$. Afterwards these variables were reduced to two independent variables. For two independent variables the degrees of freedom (DF) of the variance analysis were defined as:

\section{Linear regression (model) $\mathrm{DF}=2$}

Residual DF $=27$

Total $\mathrm{DF}=29$

The $\mathrm{F}$ test was used in the multiple regression procedure and the $t$ test to verify the hypothesis of the difference of the obtained adjustment coefficients in relation to zero. The determination coefficients $\left(\mathrm{R}^{2}\right)$ were also calculated. To compare measured and estimated values of the variable $Y$ the mean estimation error (ME) was calculated as follows: $\left(\right.$ ME $=\frac{1}{N} \sum_{1}^{N}(\mid$ Ymeasured - Yestimated $\mid)$ (Mello et. al., 2007). Statistical analyses and graphical representations were performed with the program Origin 7.0 (OriginLab Corporation).

After selecting one of the obtained models for accuracy and simplicity, this model was tested comparing measured data of several authors with those estimated by the model. To avoid bias in the selection of papers from the literature, the following sampling procedure was employed: beginning in 2000 , the sequence of all articles that allow the estimation of porosities (Ma and Mi) published in the Brazilian Journal of Soil Science (BJSC), was scanned until 10 adequate studies were found. Other three papers of previous decades that allow comparisons were also included, resulting in 13 papers for the analysis.

\section{RESULTS AND DISCUSSION}

Through experimental data (Table 2) the following models were obtained:

Model 1 (independent variables: $\mathrm{BD} / \mathrm{PD}$ and $\mathrm{Sa}$ ):

$$
\begin{gathered}
\mathrm{Ma}=0.650-1.341 \mathrm{BD} / \mathrm{PD}+0.321 \mathrm{Sa} \\
\mathrm{Mi}=0.350+0.341 \mathrm{BD} / \mathrm{PD}-0.321 \mathrm{Sa} \\
\mathrm{TP}=1-\mathrm{BD} / \mathrm{PD}
\end{gathered}
$$

Model 2 (independent variables: $\mathrm{BD}$ and $\mathrm{Sa}$ ):

$$
\begin{aligned}
& \mathrm{Ma}=0.693-0.465 \mathrm{BD}+0.212 \mathrm{Sa} \\
& \mathrm{Mi}=0.337+0.120 \mathrm{BD}-0.294 \mathrm{Sa} \\
& \mathrm{TP}=1.030-0.345 \mathrm{BD}-0.082 \mathrm{Sa}
\end{aligned}
$$

Statistical comparison of measured and estimated values (Table 3) indicated high significance degrees, equal for all $(p<0.0001)$ through the $F$ test (for regression) and t test (for the coefficients of the equations). Also, high multiple regression coefficients and low values of ME were obtained. These statistical results show the high level of adjustment accuracy of the models, which is also demonstrated by the measured and estimated values (Table 2).

Model 1 (Equations 1 and 2) allows the estimation of Ma and Mi through BD, PD, and Sa while model 2 (Equations 4 and 5), even simpler, requires only two variables, $\mathrm{BD}$ and $\mathrm{Sa}$. Texture is represented in both models by Sa only because the inclusion of $\mathrm{Si}$ and $\mathrm{Cl}$ did not result in accuracy gain. The explanation is primarily found in the fact that the sum is a constant $(\mathrm{Sa}+\mathrm{Si}+\mathrm{Cl}=1)$. Therefore, to consider them independent variables, only two would be sufficient. In addition a strong dependence was found between $\mathrm{Sa}$ and $\mathrm{Cl}$, so that one could be eliminated. We chose the sand because it leads to a slightly better adjustment. The dependence between $\mathrm{Cl}$ and $\mathrm{Sa}$ resulted in the equation $\left(R^{2}=0.897\right)$ :

$$
\mathrm{Cl}=0.78-0.78 \mathrm{Sa}
$$

It should also be noted that eliminating PD in model 2, caused no significant reduction of the accuracy in relation to model 1 (Table 3 ). The explanation for this is related to the behavior of PD that does not vary very much for mineral soils and to the fact that Sa indirectly corrects the variations, due to a high correlation between these two variables $\left(\mathrm{R}^{2}=0.803\right)$ :

$$
\mathrm{PD}=3.09-0.47 \mathrm{Sa}
$$

Considering that the MEs for both models were of the order of $0.02 \mathrm{~m}^{3} \mathrm{~m}^{-3}(2 \%)$, it is concluded that they are equivalent. On the other hand, from the point of view of application facility, model 2 requires only two variables for the estimation of $\mathrm{Ma}$ and $\mathrm{Mi}$. In this way, for estimations or to study the influence of particle size and bulk density on porosity 
Table 2. Measured and estimated values of macro (Ma) and microporosity (Mi) and measured values of sand (Sa), silt (Si), clay (Cl), particle density (PD), bulk density (BD), and total porosity (TP) for the 10 soils of table 1, subjected to three compaction levels

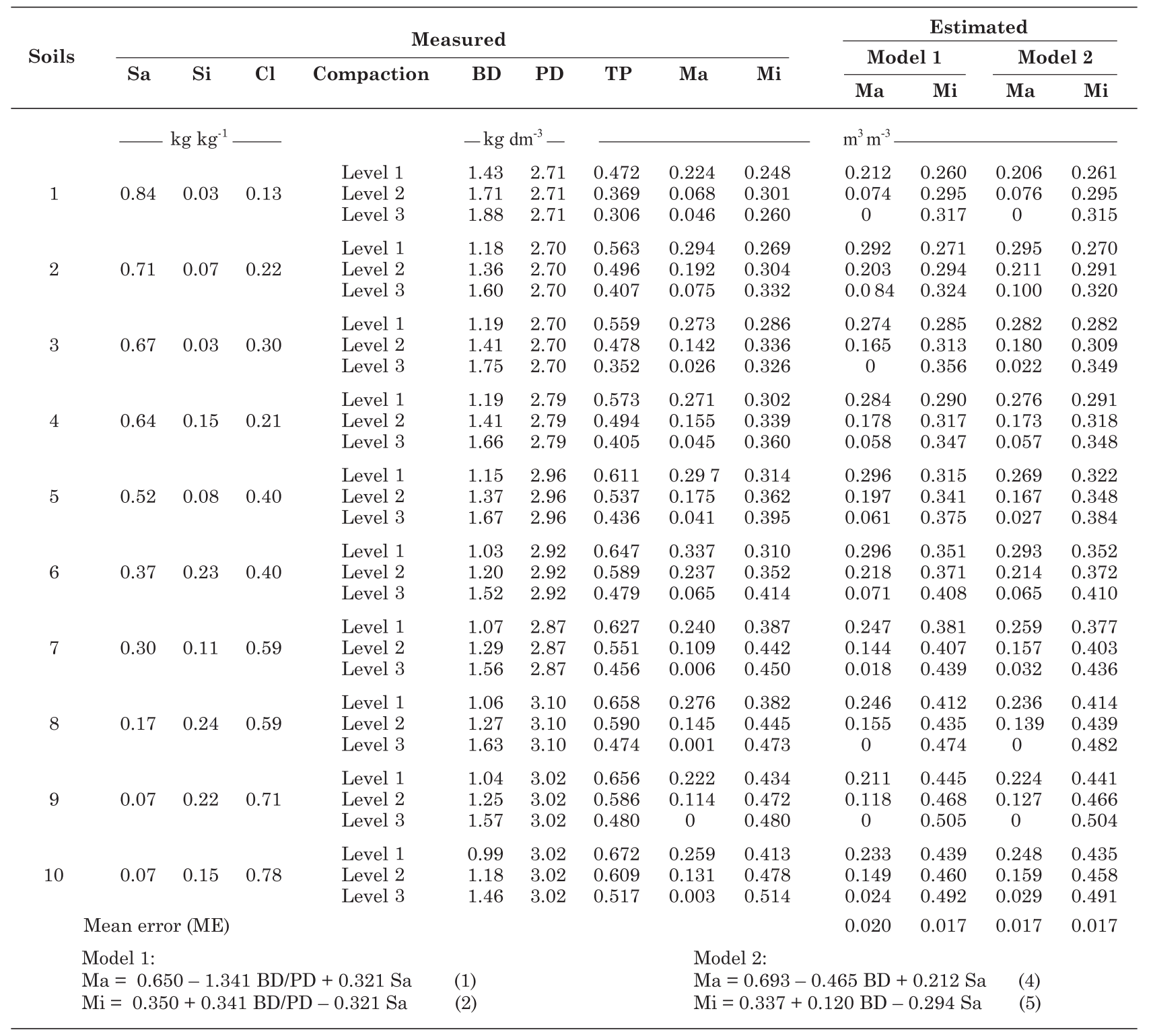

Table 3. Statistical results for model fitting

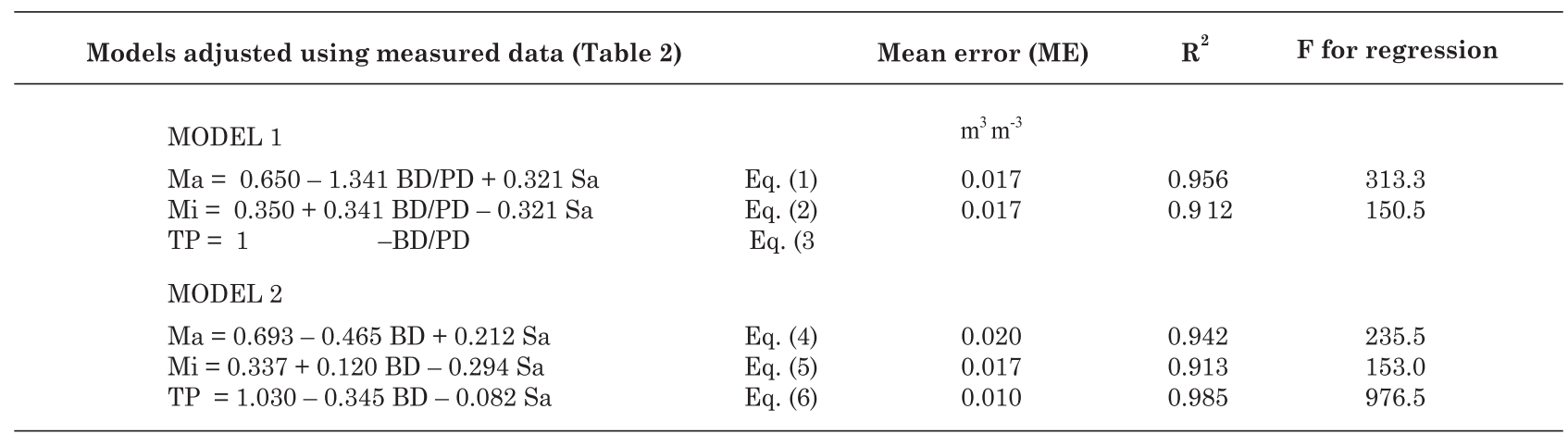

$\mathrm{T}$ test for coefficients and $\mathrm{F}$ test for regression $\mathrm{p}<0.0001$, for all equations. 
parameters, model 2 was selected as the best, represented by equations (4), (5) and (6), and also numerically by table 4 .
Through the coefficient ( -0.465 of equation 4$)$ it is possible to verify that with an increase in BD there will be an expressive reduction of $\mathrm{Ma}$, and to a lesser

Table 4. Abacus for the estimation of macroporosity (Ma), microporosity (Mi) and total porosity (TP) based on bulk density (BD) and sand content (Sa), according to model 2. Obs.: empty cells represent regions where the model is not valid

BD

$\mathrm{Sa}$

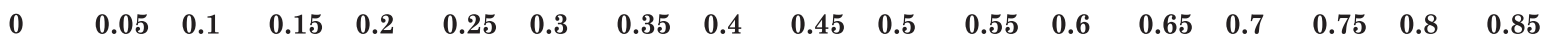

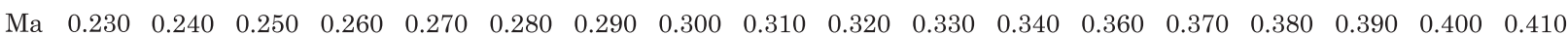

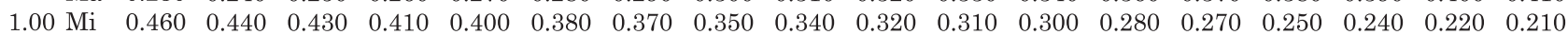

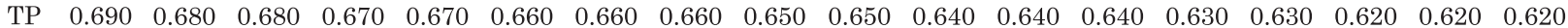

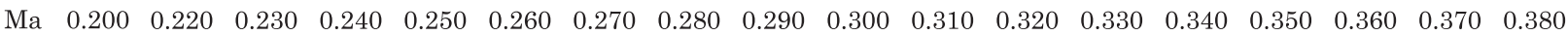
$\begin{array}{lllllllllllllllllllll}1.05 \mathrm{Mi} & 0.460 & 0.450 & 0.430 & 0.420 & 0.400 & 0.390 & 0.370 & 0.360 & 0.350 & 0.330 & 0.320 & 0.300 & 0.290 & 0.270 & 0.260 & 0.240 & 0.230 & 0.210\end{array}$

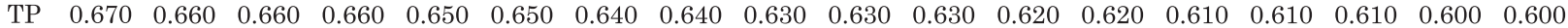

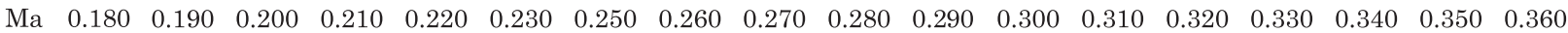

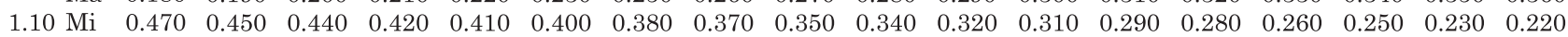

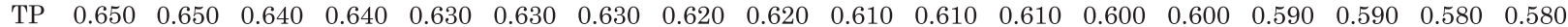

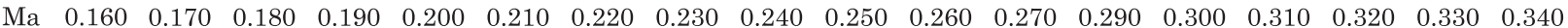

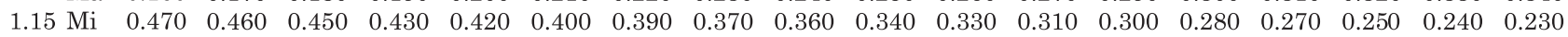
$\begin{array}{llllllllllllllllllll}\mathrm{TP} & 0.630 & 0.630 & 0.630 & 0.620 & 0.620 & 0.610 & 0.610 & 0.600 & 0.600 & 0.600 & 0.590 & 0.590 & 0.580 & 0.580 & 0.580 & 0.570 & 0.570 & 0.560\end{array}$

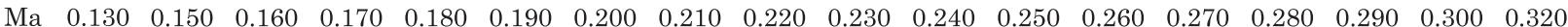
$\begin{array}{llllllllllllllllllll}1.20 \mathrm{Mi} & 0.480 & 0.470 & 0.450 & 0.440 & 0.420 & 0.410 & 0.390 & 0.380 & 0.360 & 0.350 & 0.330 & 0.320 & 0.300 & 0.290 & 0.280 & 0.260 & 0.250 & 0.230\end{array}$ $\begin{array}{llllllllllllllllllll}\mathrm{TP} & 0.620 & 0.610 & 0.610 & 0.600 & 0.600 & 0.600 & 0.590 & 0.590 & 0.580 & 0.580 & 0.580 & 0.570 & 0.570 & 0.560 & 0.560 & 0.550 & 0.550 & 0.550\end{array}$

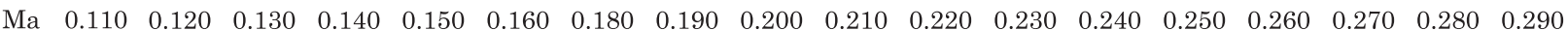

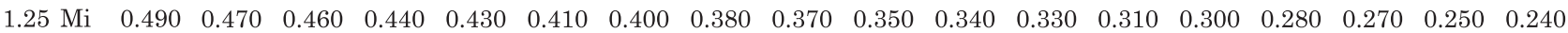

$\begin{array}{lllllllllllllllllllll}\mathrm{TP} & 0.600 & 0.590 & 0.590 & 0.590 & 0.580 & 0.580 & 0.570 & 0.570 & 0.570 & 0.560 & 0.560 & 0.550 & 0.550 & 0.550 & 0.540 & 0.540 & 0.530 & 0.530\end{array}$

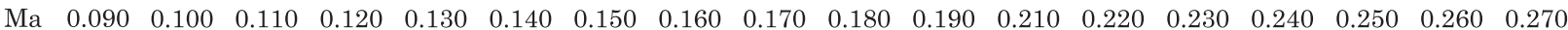

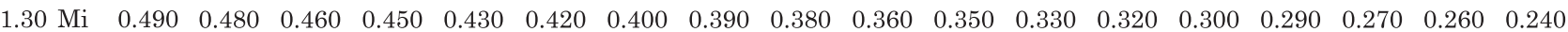

$\begin{array}{lllllllllllllllllllll}\mathrm{TP} & 0.580 & 0.580 & 0.570 & 0.570 & 0.570 & 0.560 & 0.560 & 0.550 & 0.550 & 0.540 & 0.540 & 0.540 & 0.530 & 0.530 & 0.520 & 0.520 & 0.520 & 0.510\end{array}$

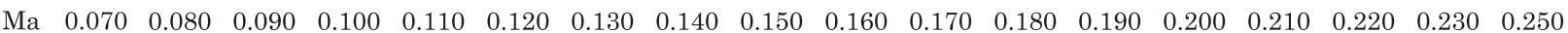

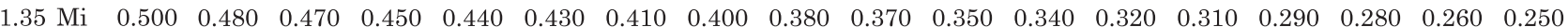

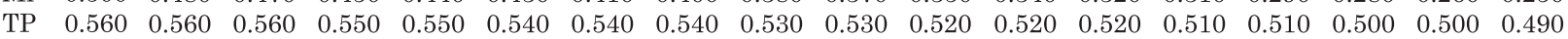

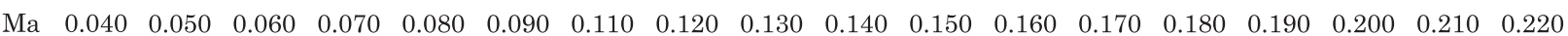

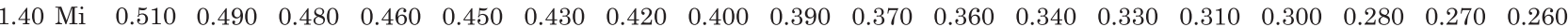

$\begin{array}{llllllllllllllllllll}\mathrm{TP} & 0.550 & 0.540 & 0.540 & 0.530 & 0.530 & 0.530 & 0.520 & 0.520 & 0.510 & 0.510 & 0.510 & 0.500 & 0.500 & 0.490 & 0.490 & 0.490 & 0.480 & 0.480\end{array}$

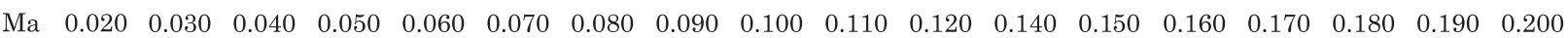

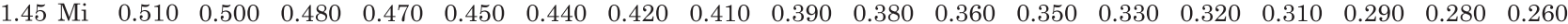
$\begin{array}{lllllllllllllllllll}\mathrm{TP} & 0.530 & 0.530 & 0.520 & 0.520 & 0.510 & 0.510 & 0.510 & 0.500 & 0.500 & 0.490 & 0.490 & 0.480 & 0.480 & 0.480 & 0.470 & 0.470 & 0.460 & 0.460\end{array}$

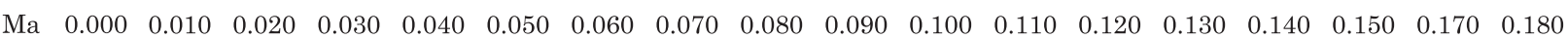

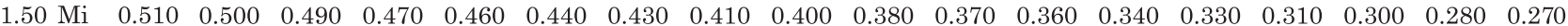
$\begin{array}{lllllllllllllllllll}\mathrm{TP} & 0.510 & 0.510 & 0.500 & 0.500 & 0.500 & 0.490 & 0.490 & 0.480 & 0.480 & 0.480 & 0.470 & 0.470 & 0.460 & 0.460 & 0.460 & 0.450 & 0.450 & 0.440\end{array}$ $\begin{array}{llllllllllllllll}\mathrm{Ma} & 0.000 & 0.010 & 0.030 & 0.040 & 0.050 & 0.060 & 0.070 & 0.080 & 0.090 & 0.100 & 0.110 & 0.120 & 0.130 & 0.140 & 0.150\end{array}$ $\begin{array}{llllllllllllllll}1.55 \mathrm{Mi} & 0.480 & 0.460 & 0.450 & 0.430 & 0.420 & 0.410 & 0.390 & 0.380 & 0.360 & 0.350 & 0.330 & 0.320 & 0.300 & 0.290 & 0.270\end{array}$ $\begin{array}{llllllllllllllll}\mathrm{TP} & 0.480 & 0.480 & 0.470 & 0.470 & 0.470 & 0.460 & 0.460 & 0.450 & 0.450 & 0.450 & 0.440 & 0.440 & 0.430 & 0.430 & 0.430\end{array}$

$\begin{array}{llllllllllllllll}\mathrm{Ma} & 0.000 & 0.010 & 0.020 & 0.030 & 0.040 & 0.050 & 0.070 & 0.080 & 0.090 & 0.100 & 0.110 & 0.120 & 0.130\end{array}$ $\begin{array}{llllllllllllll}1.60 \mathrm{Mi} & 0.460 & 0.440 & 0.430 & 0.410 & 0.400 & 0.380 & 0.370 & 0.350 & 0.340 & 0.320 & 0.310 & 0.290 & 0.280\end{array}$ $\begin{array}{llllllllllllll}\mathrm{TP} & 0.460 & 0.450 & 0.450 & 0.450 & 0.440 & 0.440 & 0.430 & 0.430 & 0.420 & 0.420 & 0.420 & 0.410 & 0.410\end{array}$ $\begin{array}{llllllllllllll}\mathrm{Ma} & 0.000 & 0.010 & 0.020 & 0.030 & 0.040 & 0.050 & 0.060 & 0.070 & 0.080 & 0.100 & 0.110\end{array}$ $\begin{array}{llllllllllll}1.65 \mathrm{Mi} & 0.430 & 0.420 & 0.400 & 0.390 & 0.370 & 0.360 & 0.340 & 0.330 & 0.310 & 0.300 & 0.290\end{array}$

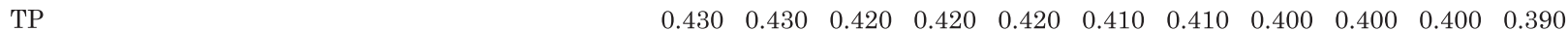

$\mathrm{Ma}$ $1.70 \mathrm{Mi}$ $\begin{array}{llllllllll}0.010 & 0.000 & 0.010 & 0.020 & 0.030 & 0.040 & 0.050 & 0.060 & 0.070 & 0.080\end{array}$ $\begin{array}{llllllllll}0.420 & 0.410 & 0.390 & 0.380 & 0.360 & 0.350 & 0.340 & 0.320 & 0.310 & 0.290\end{array}$ $\begin{array}{llllllllll}0.410 & 0.410 & 0.400 & 0.400 & 0.390 & 0.390 & 0.390 & 0.380 & 0.380 & 0.370\end{array}$ Estimated clay: $\mathrm{Cl}=0.78(1-\mathrm{Sa})$. Eq. $(7)$

$\begin{array}{llllllllllllllllll}0.78 & 0.74 & 0.70 & 0.66 & 0.62 & 0.59 & 0.55 & 0.51 & 0.47 & 0.43 & 0.39 & 0.35 & 0.31 & 0.27 & 0.23 & 0.20 & 0.16 & 0.12\end{array}$

Model 2: $\mathbf{M a}=0.693-0.465 \mathrm{BD}+0.212 \mathrm{Sa}$; $\mathbf{M i}=0.337+0.120 \mathrm{BD}-0.294 \mathrm{Sa}$ TP= 1.030 - 0.345 BD - 0.082 Sa

Units: BD kg dm ${ }^{-3}$; Ma, Mi and TP $\mathrm{m}^{3} \mathrm{~m}^{-3}$; $\mathrm{Sa} \mathrm{kg} \mathrm{kg}^{-1}$ 
extent of TP (-0.345 in equation 6$)$, besides a small increase in microporosity (+0.120 in equation 5). In relation to $\mathrm{Sa}$, the increased content is followed by an increase of $\mathrm{Ma}(+0.212$ in equation 4$)$ and a decrease of Mi (-0.294 in equation 5), as expected. In this way, the model satisfies one of the basic and minimum requisites of describing mathematically the changes in $\mathrm{Ma}, \mathrm{Mi}$ and $\mathrm{TP}$, in agreement and without conflict with previous and established knowledge in the field of Soil Physics. A quantitative character is therefore added to the description of the above properties in Model 2, allowing estimations and simulations (Figure 1).

\section{Model testing with other published data}

The following 10 papers were selected from the Brazilian Journal of Soil Science as described above: Andreola et al., 2000; Beutler et al., 2001; Stone \& Silveira, 2001; Oliveira et al., 2001; Lima \& Andrade, 2001; Albuquerque \& Reinert, 2001; Souza et al., 2001; Marques et al., 2002; Pedrotti et al., 2003; Ghini et al., 2003; Pott \& De Maria, 2003) and the three older ones: Scardua, 1972; Freire, 1975; Primavesi et al., 1984. The results are presented in table 5 together with the overall average and ME. TP data are not included since $\mathrm{TP}=\mathrm{Ma}+\mathrm{Mi}$. For $\mathrm{TP}$ the measured and estimated averages were 0.512 and $0.551 \mathrm{~m}^{3} \mathrm{~m}^{-3}$, respectively, with a ME of $0.045 \mathrm{~m}^{3} \mathrm{~m}^{-3}$.

\section{Model test for maximum bulk density estimation}

One way to test the model for extreme conditions is to compare it with other models developed specifically for the estimation of the maximum soil bulk density (MBD). Mentges et al. (2007) carried out MBD measurements with undisturbed samples by the 'Proctor test, for six soils with different Sa under different management practices. By linear regression they obtained the following model:

$$
\mathrm{MBD}=1.52669+0.45 \mathrm{Sa} \text { (Mentges et al., 2007) }
$$

To allow comparisons it is necessary to develop an equivalent equation based on the model of this study. Based on equation 4 it can be seen that while BD increases, Ma decreases until zero, its lower limit. Therefore, according to the model, MBD corresponds to the $\mathrm{BD}$ value for $\mathrm{Ma}=0$. Solving for $\mathrm{BD}$ in equation 4 , we have

$$
\mathrm{BD}=\frac{0.693+0.212 \mathrm{Sa}-\mathrm{Ma}}{0.465}
$$

Or rearranging,

$$
\mathrm{BD}=1.490+0.456 \mathrm{Sa}-2.150 \mathrm{Ma}
$$

Assuming $\mathrm{Ma}=0$, in this case BD will represent $\mathrm{MBD}$, and equation $10 \mathrm{~b}$ is reduced to:

$$
\mathrm{MBD}=1.490+0.456 \mathrm{Sa}
$$
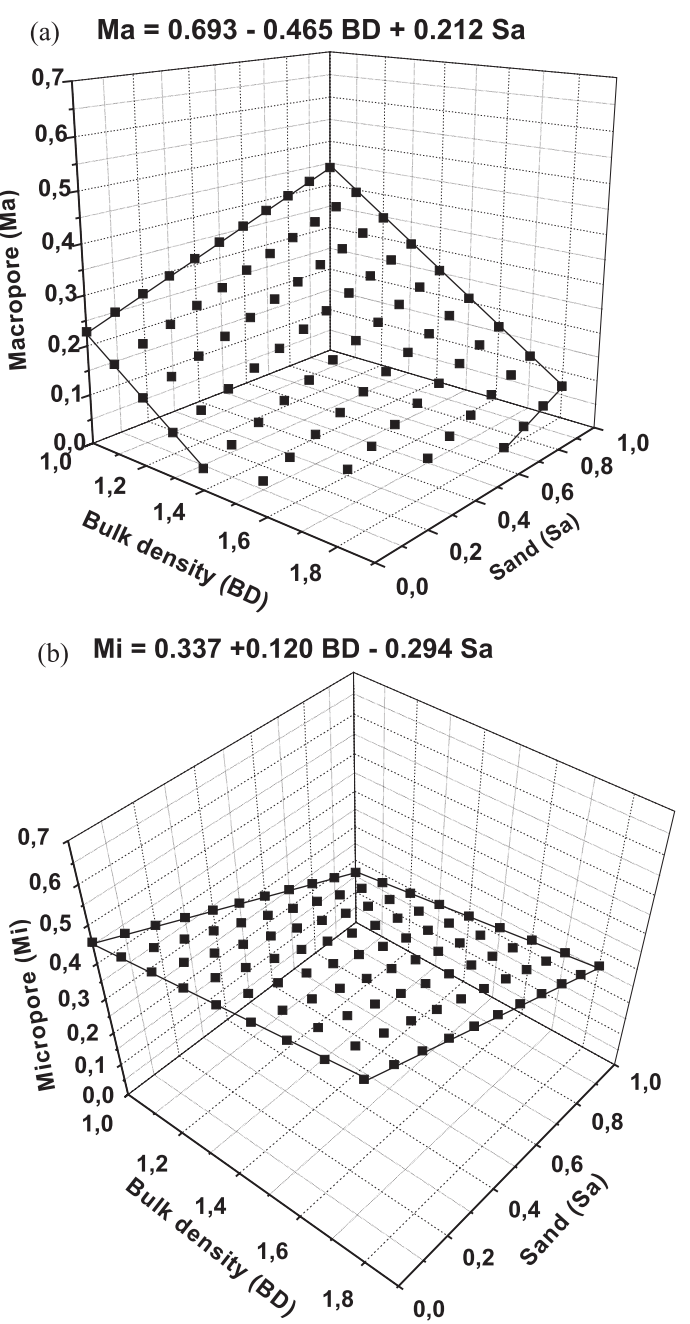

(c) TP $=1.030-0.345 \mathrm{BD}-0.082 \mathrm{Sa}$

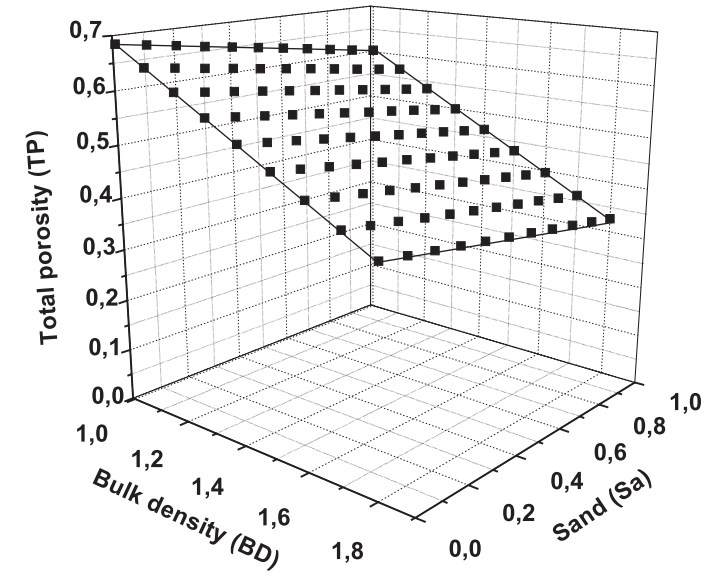

Figure 1. Three-dimensional representation of porosities according to model 2: (a) The strong variation in macroporosity is mainly related to soil bulk density and sand content.; (b) Microporosity varies mainly as function of sand content and less due to bulk density; (c): Total porosity varies mainly as a function of soil bulk density and less due to sand content. 
Table 5. Macroporosity (Ma) and microporosity (Mi) data (76 values) measured by several authors, and estimated by model 2 using sand content (Sa) and soil bulk density (BD) values as reported in the original papers

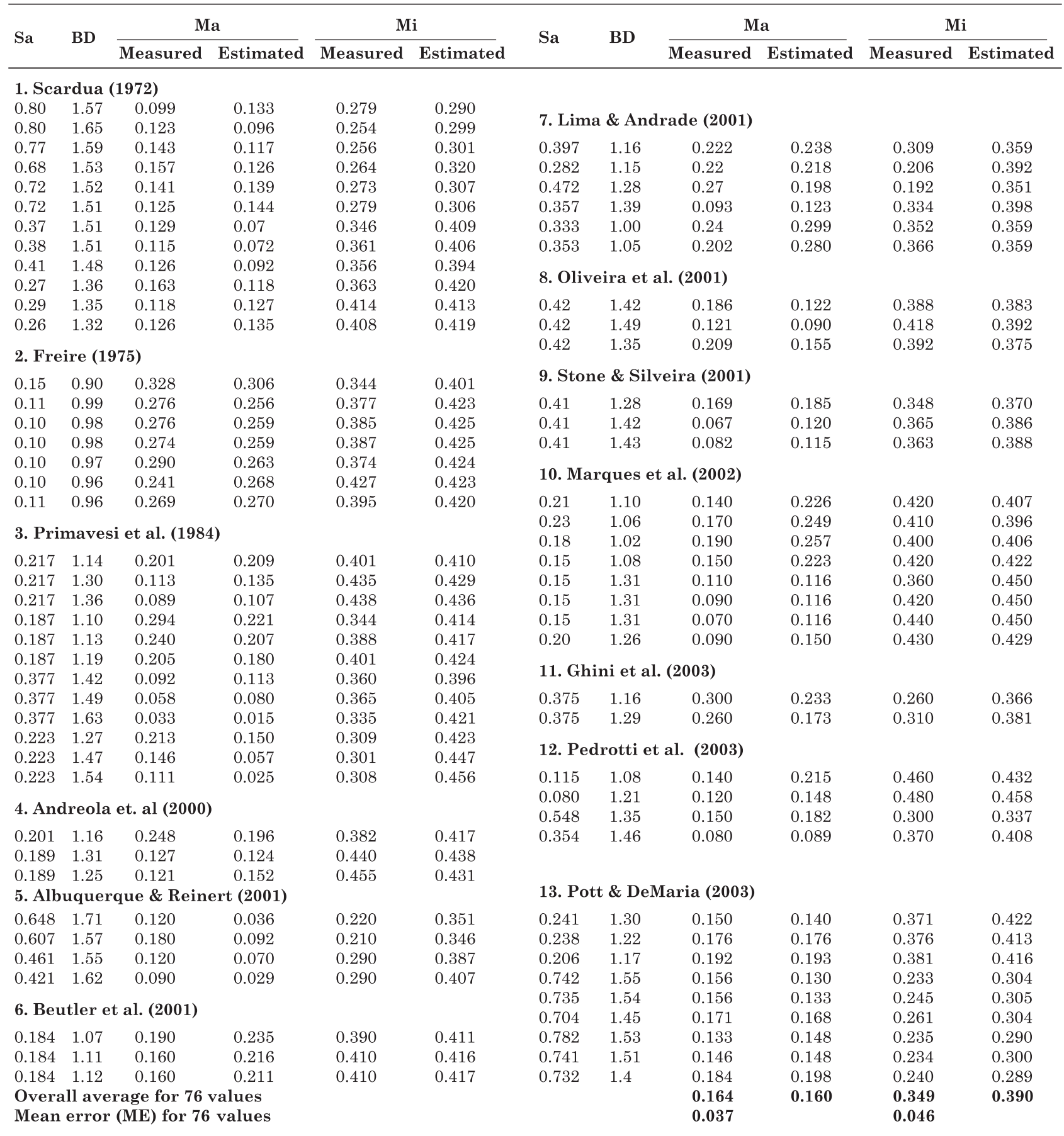

Model 2: $\mathrm{Ma}=0.693-0.465 \mathrm{BD}+0.212 \mathrm{Sa}(\mathrm{Eq} .4) . \mathrm{Mi}=0.337+0.120 \mathrm{BD}-0.294 \mathrm{Sa}$ (Eq. 5)

$\mathrm{Ma}$ e Mi expresses in $\mathrm{m}^{3} \mathrm{~m}^{-3}$. Sa in $\mathrm{kg} \cdot \mathrm{kg}^{-1}$

A comparison of both models (Equations 9 and 11) showed that their respective coefficients were close. In a more detailed comparison (Table 6), it was observed that MBD data measured and estimated by Mentges et al. (2007) and those estimated by the model proposed here were also similar. The ME low value between models (0.032) was particularly interesting. Considering that Mentges (2007) studied undisturbed samples and used a specific and precise methodology for the determination of MBD, the comparison shows a very favorable aspect of the proposed model when tested under extreme compaction. 
Table 6. Maximum bulk density (MBD) data of soils with different sand (Sa) contents cultivated under different management conditions. Column 3: measured by Mentges et al. (2007) based on the 'Proctor test; column 4: estimated by the model of Mentges et al. (2007); column 5: estimated by the model proposed in this study

\begin{tabular}{|c|c|c|c|c|}
\hline \multicolumn{4}{|c|}{ Mentges et al. (2007) } & \multirow{2}{*}{$\begin{array}{c}\text { This study } \\
\text { Estimated } \\
\text { MBD }=1.490+0.456 \mathrm{Sa}\end{array}$} \\
\hline Soil & $\mathrm{Sa}$ & Measured MBD & $\begin{array}{c}\text { Estimated } \\
\mathrm{MBD}=\mathbf{1 . 5 2 6 6 9}+0.45 \mathrm{Sa}\end{array}$ & \\
\hline & $\mathrm{kg} \mathrm{kg}^{-1}$ & & & \\
\hline Pvdaesc & 0.655 & 1.85 & 1.82 & 1.79 \\
\hline PvdaPD & 0.655 & 1.79 & 1.82 & 1.79 \\
\hline PVdlPD & 0.399 & 1.75 & 1.71 & 1.67 \\
\hline Pvdlbatata & 0.399 & 1.78 & 1.71 & 1.67 \\
\hline PVAaPD1 & 0.146 & 1.57 & 1.59 & 1.56 \\
\hline PVAaPD2 & 0.146 & 1.56 & 1.59 & 1.56 \\
\hline PVAabatata & 0.146 & 1.55 & 1.59 & 1.56 \\
\hline LVdPD & 0.338 & 1.56 & 1.68 & 1.65 \\
\hline LvafPD1 & 0.121 & 1.68 & 1.58 & 1.55 \\
\hline LVdfPD & 0.084 & 1.57 & 1.56 & 1.53 \\
\hline
\end{tabular}

Obs.: MBD Mean Error:

Measured by Mentges X estimated by Mentges: $\mathrm{ME}=0.049$

Measured by Mentges X estimated present study: $\mathrm{ME}=0.053$

Estimated by Mentges X estimated present study: $\mathrm{ME}=0.032$

Bulk density simulation corresponding to the limiting $\mathrm{Ma}\left(0.10 \mathrm{~m}^{3} \mathrm{~m}^{-3}\right)$

The value of Ma of $10 \%$ has been considered a critical limit in relation to soil aeration (Erickson, 1982; Hakansson \& Lipiec, 2000; Drewry \& Paton, 2001, Centurion et al., 2007; Melo Filho et al., 2007). In equation 4 , assuming $\mathrm{Ma}=0.10 \mathrm{~m}^{3} \mathrm{~m}^{-3}$, another expression is obtained that relates $\mathrm{BD}$ to this specific Ma value:

$$
\mathrm{BD}_{0.10}=1.275+0.456 \mathrm{Sa}
$$

One application of modeling is simulation. Using equations 11 and $12(\mathrm{Ma}=0$ and $\mathrm{Ma}=0.10$, respectively) it is possible to simulate a compaction range (Table 7). These results show that, as expected, the predicted compaction range for a clayey soil (low $\mathrm{Sa}$ ) corresponds to lower BD values. For example, for a soil with $0.20 \mathrm{~kg} \mathrm{~kg}^{-1} \mathrm{Sa}$, the compaction effect sets in at BD of $1.37 \mathrm{~kg} \mathrm{dm}^{-3}$ and increases until MBD is reached at $1.58 \mathrm{~kg} \mathrm{dm}^{-3}$. On the other hand, for a sandy soil with $0.80 \mathrm{~kg} \mathrm{~kg}^{-1} \mathrm{Sa}$, the range of the critical BD lies between 1.64 and $1.85 \mathrm{~kg} \mathrm{dm}^{-3}$.

\section{Simulation of the relative bulk density}

Relative bulk density (RBD) is defined as RBD = $\mathrm{BD} / \mathrm{MBD}$, where MBD is the value measured by axial compression $(200 \mathrm{kPa})$ or by the Proctor cylinder. This index came into use in the 1990ies as compaction index (Carter, 1990; Hakansson, 1990; Arvidsson \& Hakansson, 1991). According to several authors, values considered limiting, also called optimum relative $\mathrm{BD}$, above which yield reductions are probable, generally occur above: 0.87 (Hakansson 1990); 0.86
Table 7. Bulk density (BD) simulation in the macroporosity (Ma) range 0 to $0.10 \mathrm{~m}^{3} \mathrm{~m}^{-3}$, for different sand contents (Sa)

\begin{tabular}{ccc}
\hline Sa & $\begin{array}{c}\text { BD limit } \\
(\mathbf{M a}=\mathbf{0 . 1 0})\end{array}$ & $\begin{array}{c}\text { MBD } \\
(\mathbf{M a}=\mathbf{0})\end{array}$ \\
\hline $\mathrm{kg} \mathrm{kg}^{-1}$ & & $\mathrm{~kg} \mathrm{dm}^{-3}$ \\
0 & 1.28 & 1.49 \\
0.1 & 1.32 & 1.54 \\
0.2 & 1.37 & 1.58 \\
0.3 & 1.41 & 1.63 \\
0.4 & 1.46 & 1.67 \\
0.5 & 1.50 & 1.72 \\
0.6 & 1.55 & 1.76 \\
0.7 & 1.59 & 1.81 \\
0.8 & 1.64 & 1.85 \\
\hline
\end{tabular}

Limit bulk density $(\mathrm{Ma}=0.10): \mathrm{BD}=1.275+0.456 \mathrm{Sa}$.

Maximum bulk density $(\mathrm{Ma}=0): \mathrm{MBD}=1.490+0.456 \mathrm{Sa}$.

(Arvidsson \& Hakansson, 1991); 0.84 and 0.87, (Torres \& Saraiva, 1999), 0.80-0.84 (Beutler et al, 2005 e 2008). According to Torres \& Saraiva (1999), relative compaction results above $0.86(86 \%)$ are considered as harmful in most years causing yield reduction due to $\mathrm{BD}$ increase, Ma reduction, as well as changes in other soil properties such as hydraulic conductivity, permeability and penetration resistance. In fine sandy loams, classified as Orthic Humo-Ferric Podzols, Carter (1990) found a correlation $\left(\mathrm{R}^{2}=85 \%\right)$ between RBD and macropores. In a detailed review of this subject, Hakansson \& Lipiec (2000) mentioned that the limiting RBD in Swiss soils with clay content varying from 2 to $60 \%$ was about 0.87 , independently of the texture. They correlated the soil water potential 
to RBD using data collected in Poland from soils of different textures. Figure 3 of the cited study shows that the line of RBD crosses the line of the macroporosity $10 \%\left(\mathrm{Ma}=0.10 \mathrm{~m}^{3} \mathrm{~m}^{-3}\right)$ at the 0.87 value.

The merit of both compaction indexes RBD and Ma lies in the fact that they are independent of texture for data interpretation. Considering two soils of different textures, by the Ma criterion, the less compacted soil is the one with higher $\mathrm{Ma}$, and by the $\mathrm{RBD}$ criterion, the soil with the lower value. Besides these similarities, both criteria allow the determination of generic parameters for the critical limit for soil aeration: below $0.10 \mathrm{~m}^{3} \mathrm{~m}^{-3}$ for the $\mathrm{Ma}$ index and above 0.87 for the RBD index.

Regarding the modeling of RBD, two models are possible. Dividing the BD by MBD (Equation 11) the first one is calculated by:

$$
\mathrm{RBD}=\frac{\mathrm{BD}}{\mathrm{MBD}}=\frac{\mathrm{BD}}{0.456 \mathrm{Sa}+1.490}
$$

In this way, it is possible to estimate RBD measuring only BD and Sa, eliminating the measurement of MBD.

In the further development of the modeling two fundamental questions arise: - Is it possible to establish a correspondence between $\mathrm{Ma}$ and RBD?; - Which is the importance of Ma $0.10 \mathrm{~m}^{3} \mathrm{~m}^{-3}$ in terms of RBD, or which is the importance of RBD 0.87 in terms of Ma? To reply to these questions it is necessary to establish a general equation that unifies the universe of the variables of the two compaction indexes, RBD and Ma. Dividing equation10a by itself considering $\mathrm{Ma}=0$ in the denominator, we have:

$$
\mathrm{RBD}=\frac{\mathrm{BD}}{\mathrm{MBD}}=\frac{\frac{0.693+0.212 \mathrm{Sa}-\mathrm{Ma}}{0.465}}{\frac{0.693+0.212 \mathrm{Sa}-\mathrm{Ma}(=0)}{0.465}}
$$

or

$$
\mathrm{RBD}=\frac{0.693+0.212 \mathrm{Sa}-\mathrm{Ma}}{0.693+0.212 \mathrm{Sa}}
$$

And finally

$$
\mathrm{RBD}=1-\frac{\mathrm{Ma}}{0.693+0.212 \mathrm{Sa}}
$$

Or solving for $\mathrm{Ma}$

$$
\mathrm{Ma}=(1-\mathrm{RBD}) \mathrm{x}(0.693+0.212 \mathrm{Sa})
$$

The simulation of RBD as a function of $\mathrm{Ma}(0-30 \%)$, using equation 16 , proves that the RBD index of compaction degree behaves practically independently of Sa for a given Ma value (Table 8), and that the value 0.87 corresponds to $0.10 \mathrm{~m}^{3} \mathrm{~m}^{-3} \mathrm{Ma}$, representing a proof of the hypothesis proposed by Hakansson \& Lipiec (2000).
Hakansson \& Lipiec (2000) analyzed 55 assays in eight crops and proposed a classification taking into account the compaction degree as related to the optimum RBD. Through equation 17 or even table 8, it is possible to approximately estimate the corresponding values of $\mathrm{Ma}$ :

Group 1: RBD $0.87\left(\mathrm{Ma} 0.10 \mathrm{~m}^{3} \mathrm{~m}^{-3}\right)$. Barley (Hordeum vulgare L.), wheat (Triticum aestivum L.), sugarbeet (Beta vulgaris L.),

Group 2: RBD 0.85 (Ma $0.12 \mathrm{~m}^{3} \mathrm{~m}^{-3}$ ). Pea (Pisum sativum L.), oat (Avena sativa L.).

Group 3: RBD $0.84\left(\mathrm{Ma} 0.13 \mathrm{~m}^{3} \mathrm{~m}^{-3}\right.$ ). Rape (Brassica species), faba bean (Vicia faba L.)

Group 4: RBD $0.82\left(\mathrm{Ma} 0.14 \mathrm{~m}^{3} \mathrm{~m}^{-3}\right)$. Potato (Solanum tuberosum L.).

\section{Fundamentals and unification of the models}

Both models, 1 (Equations 1 to 3) and 2 (Equations 4 to 6), follow the theoretical condition that $\mathrm{Ma}+\mathrm{Mi}$ $=\mathrm{TP}$. That is, equation $1+$ equation $2=$ equation 3 in Model 1; and equation $4+$ equation $5=$ equation 6 in Model 2. Moreover, in model 1, this sum leads to the theoretical and well-known representation of TP (Equation 3). In this equation, the number 1 is a unitary volume of soil while TP is the volume fraction represented by pores, and $\mathrm{BD} / \mathrm{PD}$ volume fraction occupied by the solid phase. Therefore, the linear theoretical variation of equation 3, (TP) $\mathrm{x}(\mathrm{BD} / \mathrm{PD})$ was also empirically adopted in equation $1,(\mathrm{Ma}) \mathrm{x}$ (BD/PD), and 2, (Mi) x (BD/PD). In other words, in model 1, Ma, Mi as well TP are linearly related with the variation of solid fraction of soil volume (BD/PD). On the other hand, model 2 can be considered similar to model 1 as a result of eliminating the variable PD.

Table 8. Simulation of the relative soil bulk density (RBD) in the macroporosity (Ma) interval 0 - $30 \%$ for sand contents (Sa) from 0 to $0.80 \mathrm{~kg} \mathrm{~kg}^{-1}(0-80 \%)$

\begin{tabular}{llll}
\hline & \multicolumn{2}{c}{$\mathbf{R B D}=\mathbf{1}-\frac{\mathbf{M a}}{\mathbf{0 . 6 9 3}+\mathbf{0 . 2 1 2} \mathbf{~ S a}} \mathbf{( E q . ~ 1 6 )}$} \\
\cline { 2 - 3 } $\mathbf{M a}$ & $\mathbf{S a} \mathbf{0}$ & $\mathbf{S a}=\mathbf{0 . 4 0}$ & $\mathbf{S a}=\mathbf{0 . 8 0}$ \\
\cline { 2 - 3 } 0.00 & 1.00 & 1.00 & 1.00 \\
0.02 & 0.97 & 0.97 & 0.98 \\
0.04 & 0.94 & 0.95 & 0.95 \\
0.06 & 0.91 & 0.92 & 0.93 \\
0.08 & 0.88 & 0.90 & 0.91 \\
$\mathbf{0 . 1 0}$ & $\mathbf{0 . 8 6}$ & $\mathbf{0 . 8 7}$ & $\mathbf{0 . 8 8}$ \\
0.12 & 0.83 & 0.85 & 0.86 \\
0.14 & 0.80 & 0.82 & 0.84 \\
0.16 & 0.77 & 0.79 & 0.81 \\
0.18 & 0.74 & 0.77 & 0.79 \\
0.20 & 0.71 & 0.74 & 0.77 \\
0.22 & 0.68 & 0.72 & 0.74 \\
0.24 & 0.65 & 0.69 & 0.72 \\
0.26 & 0.62 & 0.67 & 0.70 \\
0.28 & 0.60 & 0.64 & 0.68 \\
0.30 & 0.57 & 0.61 & 0.65 \\
\hline
\end{tabular}


The question can be raised on how far it is possible to unify the models. For this purpose, in model 1, $\mathrm{BD} / \mathrm{PD}$ is substituted by TP and in model $2, \mathrm{BD}$ is replaced by TP, as follows: in model 1, taking equation 3 in the form $\mathrm{BD} / \mathrm{PD}=1-\mathrm{TP}$ and substituting the result in equations 1 and 2 we obtain $\mathrm{Ma}$ and $\mathrm{Mi}$ as a function of TP. In model 2, in a similar way, solving for BD in equation 6 , we obtain $\mathrm{BD}=2.986-2.899 \mathrm{TP}-0.238 \mathrm{Sa}$, and introducing this result into equations 4 and 5 , we obtain $\mathrm{Ma}$ and $\mathrm{Mi}$ as a function of TP. In this way it was possible to obtain the same equations for both models, with negligible variations (the difference depending on the coefficients which ranged from 0.001 to a maximum of 0.007), and a unified model can be written as:

$$
\begin{aligned}
& \mathrm{Ma}=-0.691+1.341 \mathrm{TP}+0.321 \mathrm{Sa} \\
& \mathrm{Mi}=0.691-0.341 \mathrm{TP}-0.321 \mathrm{Sa}
\end{aligned}
$$

So, it is important to recognize that the form by which TP is obtained defines the adopted model: Model 1: when using equation 3 to obtain TP, and applying this value in equation 17 and 18, Ma and Mi are obtained. Model 2: when using equation 6 to obtain $\mathrm{TP}$, and applying this value in the same equations, 17 and $18 \mathrm{Ma}$ and $\mathrm{Mi}$ are obtained.

\section{The quality of model 2 and its limitations}

Mello et al. (2007) developed a pedotransfer model for the estimation of drainable porosity (DP). They described the accuracy of the model as good, due to its high determination coefficient $\left(\mathrm{R}^{2}=0.8361\right)$ and low ME $\left(0.024 \mathrm{~m}^{3} \mathrm{~m}^{-3}\right)$. For model 2, which is composed of two equations, we obtained $\mathrm{R}^{2}=0.913$ and $\mathrm{a} \mathrm{ME}=$ $0.017 \mathrm{~m}^{3} \mathrm{~m}^{-3}$ for $\mathrm{Mi}$, and $\mathrm{R}^{2}=0.942, \mathrm{ME}=$ $0.020 \mathrm{~m}^{3} \mathrm{~m}^{-3}$ for Ma (Tables 2 and 3). Considering these results, the accuracy of model 2 can be considered good, comparatively. Employing these equations to estimate data published elsewhere, which are not specific for modeling, an increase of the ME was verified, with Mi being overestimated by $0.04 \mathrm{~m}^{3} \mathrm{~m}^{-3}$, with a ME of $0.046 \mathrm{~m}^{3} \mathrm{~m}^{-3}$ (Table 5). On the other hand, the equation for Ma was verified to have a lower ME, $0.037 \mathrm{~m}^{3} \mathrm{~m}^{-3}$ and unbiased, so that it is classified as medium precise for the estimations. In a general way, similar models of pedotransfer are focused on hydric aspects, while in our study the focus is soil compaction. Taking for example $\mathrm{Ma} 0.10 \mathrm{~m}^{3}$ $\mathrm{m}^{-3}$ as the limit to define compacted or uncompacted fields, considering the 76 points of table 5 as agricultural fields, the estimated values define with good accuracy 56 fields. Another aspect is that the Ma model allows modeling two additional properties, MBD and RBD, with good performance so that it can be considered appropriate for simulations.

Limitations regarding the domain of the variables can be verified in table 1 . It is especially recommended to observe the upper limit of $0.84 \mathrm{~kg} \mathrm{~kg}^{-1}$ for $\mathrm{Sa}$, and also for use in non organic soils of low $\mathrm{C} \%$, increasing for clayey soils up to the limit $\mathrm{C} \%=1.75(\mathrm{OM}=3.0 \%)$.
This last variable was not considered in our model because it did not improve accuracy, being negatively correlated with $\mathrm{Sa}: \mathrm{R}^{2}=0.736$.

With respect to the use of air-dried fine earth (ADFE), the study was first performed with samples in their natural state, undisturbed. It was however difficult to obtain samples in a sufficiently wide range of representative $\mathrm{BD}$ s for each texture. In the evaluations, BD and consequently Ma presented little variation because most variation in $\mathrm{BD}$ was due to texture. In summary, to study soil compaction it was considered essential to obtain a low, a medium and a high $\mathrm{BD}$ value for each texture. In a second phase, samples were tested simulating BD with air-dried fine earth. These tests showed that when ADFE is compacted up to the BD value of the undisturbed sample, the results were similar, allowing the use of this procedure, and validation studies were added to this study. Several reports compare undisturbed and disturbed samples without considering the differences in density that influence especially measurements at low water potentials. Hervias (2009), studied several pore types in a Palehumult, among these pores of rapid drainage (0-60 hPa), expressed volumetrically in \%, i.e., Ma \% and compared treatments of undisturbed and disturbed ADFE. In this case, samples were packed trying to reproduce the undisturbed state. Six cycles of drying and wetting were performed, verifying Ma of 10.1 and $9.1 \%$ before cycles and 7.5 and $6.4 \%$ after six cycles, respectively, for undisturbed and disturbed samples (Hervias, 2009). Since drying and wetting cycles were not used in this study, comparisons were only made for the samples without cycles; although there was no equality, results were very similar.

\section{CONCLUSIONS}

1. Models 1 and 2, composed of equations to calculate Macro (Ma) and Microporosity (Mi) provided accurate estimates. Model 2 was selected as best because it does not require particle density (PD).

2. Comparing model 2 with measured data, published by other authors, Ma and Mi values were obtained with medium accuracy, however Ma more accurately than Mi.

3. Transforming the Ma equation for the simulation of the maximum bulk density (MBD) it was concluded that the resulting model estimates this property accurately, compared to literature data.

4. Transforming the Ma equation for the simulation of the relative bulk density (RBD) as a function of $\mathrm{Ma}$ and sand content (Sa), it was shown that RBD has little variation, practically independent of the texture (Sa). Furthermore, the hypothesis of Hakansson \& Lipiec (2000) was proven, in that RBD $=0.87$ corresponds very closely to $\mathrm{Ma}=0.10 \mathrm{~m}^{3} \mathrm{~m}^{-3}(10 \%)$. 


\section{LITERATURE CITED}

ALBUQUERQUE, J.A. \& REINERT, D.J. Densidade radicular do milho considerando os atributos de um solo com horizonte B textural. R. Bras. Ci. Solo, 25:539-549, 2001.

AMADO, T.J.C.; CONCEIÇÃO, P.C.; BAYER, C. \& ELTZ, F.L.F. Qualidade do solo avaliada pelo "Soil Quality Kit test" em dois experimentos de longa duração no Rio Grande do Sul. R. Bras. Ci. Solo, 31:109-121, 2007.

ANDREOLA, F.; COSTA, L.M. \& OLSZEVSKI, N. Influência da cobertura vegetal de inverno e da adubação orgânica e, ou, mineral sobre as propriedades físicas de uma terra roxa estruturada. R. Bras. Ci. Solo, 24:857-865, 2000.

ARVIDSSON, J. \& HAKANSSON, I.A. A model for estimating crop yield losses caused by soil compaction. Soil Tillage Res., 20:319-332, 1991.

BAVER L.D. The bulk density. In: BAVER L.D. ed. Soils phisics. 3.ed. New York, J. Wiley \& Sons, 1966. p.48-80.

BeUtler, A.N.; CENTURION, J.F., ROQUE, C.G. \& FERRAZ, M.V. Densidade relativa ótima de Latossolos Vermelhos para a produtividade de soja. R. Bras. Ci. Solo, 29:843-849, 2005.

BEUTLER, A.N.; FREDDI, O.S.; LEONE, C.L. \& CENTURION, J.F. Densidade do solo relativa e parâmetro "S" como indicadores da qualidade física para culturas anuais. $\mathrm{R}$. Biol. Ci. Terra, 8:27-36, 2008.

BEUTLER, A.N.; SILVA, M.L.N.; CURI, N.; FERREIRA, M.M.; CRUZ, J.C. \& PEREIRA FILHO, I.A. Resistência à penetração e permeabilidade de Latossolo Vermelho distrófico típico sob sistemas de manejo na região dos cerrados. R. Bras. Ci. Solo, 25:167-177, 2001.

BLAKE, G.R. Bulk density. In: BLACK, C.A., ed. Methods of soil analysis: Physical and mineralogical properties, including statistics of measurement and sampling. Madison, American Society of Agronomy, 1965. p.374390 .

CARTER, M.R. \& JOHNSTON, H.W. Association of macroporosity and relative saturation of root rot severity of spring cereals. Plant Soil, 120:149-152, 1989.

CARTER, M.R. Relative measures of soil bulk density to characterize compaction in tillage studies on fine sandy loams. Can. J. Soil Sci.70, 425-433, 1990.

CENTURION, J.F.; FREDDI, O.S.; ARATANI, R.G.; METZNER, A.F.M.; BEUTLER, A.N. \& ANDRIOLI, I. Influência do cultivo da cana-de-açúcar e da mineralogia da fração argila nas propriedades físicas de Latossolos Vermelhos. R. Bras. Ci. Solo, 31:199-209, 2007.

DREWRY, J.J. \& PATON, R.J. Effect of simulated dairy cow treading on soil physical properties and ryegrass pasture yield. New Zealand J. Agric. Res., 44:181-190, 2001.

ERICKSON, A.E. Tillage effects on soil aeration. In: PREDICTING TILLAGE EFFECTS ON SOIL PHYSICAL PROPERTIES AND PROCESSES, Madison, 1982 Proceedings... Madison, American Society of Agronomy, 1982. p.91-104.
FEITOZA, M.Z.N. Estimativa da porosidade drenável por diferentes metodologias. Recife, Universidade Federal Rural de Pernambuco, 2006. 48p.

FIDALSKI, J. \& TORMENA, C.A. Funções de pedotransferência para as curvas de retenção de água e de resistência do solo à penetração em sistemas de manejo com plantas de cobertura permanente em citros. Ci. Rural, 37:13161322, 2007.

FREIRE, J.C. Retenção de umidade em perfil Oxissol do município de Lavras, Minas Gerais. Piracicaba, Escola Superior de Agricultura Luiz de Queiroz, 1975. 76p. (Tese de Mestrado)

GHINI, R.; PATRICIO, F.R.A.; SOUZA, M.D.; SINIGAGLIA, C.; BARROS, B.C.; LOPES, M.E.B.M.; TESSARIOLI NETO, J. \& CANTARELLA, H. Efeito da solarização sobre propriedades físicas, químicas e biológicas de solos. R. Bras. Ci. Solo, 27:71-79, 2003.

HAKANSSON, I. A method for characterizing the state of compactness of the plough layer. Soil Tillage Res.,16:105120,1990

HAKANSSON, I. \& LIPIEC, J. A review of the usefulness of relative bulk density values in studies of soil structure and compaction. Soil Tillage Res., 53:71-85, 2000.

HERVIAS, C.E.L. Caracterización del monto, funcionalidad y evolución del sistema poroso de un Palehumult al ser sometido a ciclos de formación de estructura. Valdivia, Universidade Austrak do Chile, 2009. 77p.

KIEHL, E.J. Manual de edafologia: Relações solo-planta. São Paulo, Ceres, 1979. 264p.

LIMA, P.M.P. \& ANDRADE, H. Erodibilidade entressulcos e atributos de solos com B textural e B latossólico do sul de Minas Gerais. R. Bras. Ci. Solo, 25:463:474, 2001.

MARQUES, J.D.; LIBARDI, P.L. \& Jong van Lier, Q. Relação entre horizontes pedológicos e propriedades hidráulicas em dois latossolos. R. Bras. Ci. Solo, 26:567-577, 2002.

MELLO, C.R.; GOMES, N.M.; SILVA, A.M. \& JUNQUEIRA JUNIOR, J.A. Modelagem de atributos físico-hídricos do solo numa bacia hidrográfica da região do Alto Rio Grande, MG. R. Bras. Ci. Solo, 31:845-852, 2007.

MELO FILHO, J.F.; SOUZA, A.L.V. \& SOUZA, L.S Determinação do índice de qualidade subsuperficial em um Latossolo Amarelo coeso dos Tabuleiros Costeiros, sob floresta natural. R. Bras. Ci. Solo, 31:1599-1608, 2007.

MENTGES, M.I.; FONTANELA, E.; REICHERT, J.M.; REINERT, D.J. \& SUZUKI, L.E.A.S. Densidade máxima pelo ensaio de Proctor normal para seis solos em diferentes manejos e sua relação com o teste de compressão uniaxial. In: CONGRESSO BRASILEIRO DE CIÊNCIA DO SOLO, 31., Gramado, 2007. Resumos... Porto Alegre, Sociedade Brasileira de Ciência do Solo, Núcleo Regional Sul, 2007. p. 96-97.

OLIVEIRA, J.O.A.; VIDIGAL FILHO, P.S.; TORMENA, C.A.; PEQUENO, M.G.; SCAPIM, C.A.; MUNIZ, A.S. \& SAGRILO, E. Influência de sistemas de preparo do solo na produtividade da mandioca. R. Bras. Ci. Solo, 25:443450, 2001 
PEDROTTI, A.; FERREIRA, M.M.; CURI, N.; SILVA, M.L.N.; LIMA, J.M. \& CARVALHO, R. Relação entre atributos físicos, mineralogia de fração argila e formas de alumínio no solo. R. Bras. Ci. Solo, 27:1-9, 2003

POTT, C.A. \& DE MARIA, I.C. Comparação de métodos de campo para determinação da velocidade de infiltração básica. R. Bras. Ci. Solo, 27:19-27, 2003.

PRIMAVESI, O.; MELO, F.A.F. \& LIBARDI, P.L. Seleção preliminar de parâmetros físicos mais adequados para estudar o efeito de compactação de amostras de solo sobre a produção de matéria seca vegetal de feijoeiro (Phaseolus vulgaris L.). Anais ESALQ, 41:449-483, 1984.

RIBEIRO, K.D.; NASCIMENTO, J.M.S.; GOMES, N.M.; LIMA, L.A. \& MENEZES, S.M. Relações matemáticas entre porosidade drenável e condutividade hidráulica do solo saturado. R. Bras. Eng. Agríc. Amb., 11:600-606, 2007.

.SANTOS, F.C.; NOVAIS, R.F.; NEVES, J.C.L.; FOLONI, J.M.; ALBUQUERQUE FILHO, M.R. \&. KER, J.C. Produtividade e aspectos nutricionais de plantas de soja cultivadas em solos de cerrado com diferentes texturas. R. Bras. Ci. Solo, 32:2015-2025, 2008.

SCARDUA, R. Porosidade livre de água de dois solos do município de Piracicaba, S.P. Piracicaba, Escola Superior de Agricultura Luiz de Queiroz, 1972. 83p. (Tese de Mestrado)
SOUZA, Z.M.; SILVA, M.L.S.; GUIMARÃES, G.L.; CAMPOS, D.T.S.; CARVALHO, M.P. \& PEREIRA, G.T. Variabilidade espacial de atributos físicos em um Latossolo Vermelho distrófico sob semeadura direta em selvíria (MS). R. Bras. Ci. Solo, 25:699-707, 2001.

SPIEGEL, M.R. Estatística. São Paulo, Mc Graw-Hill, 1971. 590 p.

STOLF, R. Programa de regressão múltipla (REGR) de fácil manipulação e transformação de arquivos eletrônicos de dados. Geociências, 15:425-433, 1996.

STOLF, R. A compactação do solo e perspectivas da subsolagem em citrus. Laranja, 2:283-308, 1987.

STONE, L.F. \& SILVEIRA, P.M. Efeitos do sistema de preparo e da rotação de culturas na porosidade e densidade do solo. R. Bras. Ci. Solo, 25:395-401, 2001.

TORRES, E. \& SARAIVA, O.F. Camadas de impedimento do solo em sistemas agrícolas com a soja. Londrina, Embrapa Soja, 1999. 58p. (Circular Técnica, 23)

WU, L.; VOMOCIL, J.A. \& CHILDS, S.W. Particle size, aggregate size, pore size, and water retention. Soil Sci. Soc. Am. J., 54:952-956, 1990. 